\title{
The Mitochondrial Receptor Complex: A Central Role of MOM22 in Mediating Preprotein Transfer from Receptors to the General Insertion Pore
}

\author{
Michael Kiebler, " Petra Keil, $†$ Helmut Schneider, " $\ddagger$ \\ Ida J. van der Klei, " Nikolaus Pfanner, $\dagger$ \\ and Walter Neupert* \\ *Institut für Physiologische Chemie \\ Universität München \\ 80336 München \\ Federal Republic of Germany \\ †Biochemisches Institut \\ Universität Freiburg \\ 79104 Freiburg \\ Federal Republic of Germany
}

\section{Summary}

The receptor complex in the mitochondrial outer membrane, which consists of at least seven different proteins, is responsible for the recognition and translocation of cytosolically synthesized preproteins. Two of its subunits, MOM19 and MOM72, function as surface receptors for preproteins. Four other subunits (MOM38, MOM30, MOM8, and MOM7) have been suggested to constitute the general insertion pore (GIP). Here we report on the structure and function of MOM22. MOM22 is anchored in the outer membrane by a single transmembrane segment. The highly negatively charged $\mathrm{N}$-terminal domain is exposed to the cytosol and the C-terminal domain to the intermembrane space. MOM22 appears to be a central component of the receptor complex, required for the transfer of preproteins from the receptors to the GIP. We speculate that the negatively charged domain of MOM22 is involved in the transfer of positively charged signal sequences of preproteins.

\section{Introduction}

Translocation of preproteins across intracellular membranes is a process of considerable complexity involving a series of steps such as recognition, unfolding, membrane insertion, membrane passage, processing, and folding of the proteins (Wickner and Lodish, 1985; Neupert et al., 1990; Baker and Schatz, 1991; Keegstra and von Heijne, 1992; Rapoport, 1992; Sanders and Schekman, 1992). It is therefore not unexpected that not only a large number of components are required for preprotein translocation, but that these components are also organized in multisubunit complexes (Alberts and Miake-Lye, 1992).

Previous studies on the import of preproteins into mitochondria led to the identification of a protein complex in the mitochondrial outer membrane that mediates the specific recognition, membrane insertion, and translocation of preproteins across the outer membrane (Kiebler et al., 1990;

FPresent address: Sandoz Pharma Aktiengesellschaft, 4002 Basel, Switzerland.
Moczko et al., 1992; Söllner et al., 1992). Seven different proteins, termed mitochondrial outer membrane proteins (MOMs), were found in this receptor complex. Two components of the complex were identified as receptors for preproteins. The $19 \mathrm{kd}$ protein MOM19 seems to be the main receptor, involved in the import of most preproteins analyzed (Söllner et al., 1989, 1992; Steger et al., 1990; Pfanner et al., 1990; Schneider et al., 1991; Becker et al., 1992; Lill et al., 1992). In particular, MOM19 was found to be required for the import of preproteins with $\mathrm{N}$-terminal signal sequences (presequences) as well as for the import of several noncleavable preproteins. The $72 \mathrm{kd}$ protein MOM72 preferentially functions as receptor for a class of noncleavable preproteins with internal signal sequences, such as the precursors of the inner membrane proteins ADPIATP carrier (AAC) and phosphate carrier (Söllner et al., 1990, 1992; Steger et al., 1990). In addition, both receptors possess overlapping specificities, allowing the import of MOM72-dependent precursors via MOM19 and vice versa, albeit with reduced efficiency (Steger et al., 1990; Hines et al., 1990; Söllner et al., 1992; Hines and Schatz, 1993). The two import receptors have a similar topology in that they are anchored in the outer membrane by a hydrophobic $\mathrm{N}$-terminal segment, while the rest of the molecule is hydrophilic and exposed to the cytosol, where it is easily degraded by added proteases (Hase et al., 1984; Steger et al., 1990; Schneider et al., 1991).

Four other components of the receptor complex, MOM38 (also termed ISP42), MOM30, MOM8, and MOM7, have a different topology and function (Vestweber et al., 1989; Baker et al., 1990; Kiebler et al., 1990; Moczko et al., 1992; Söllner et al., 1992). They are in proximity of precursors arrested in the general insertion pore (GIP) and assumed to contribute to formation of the pore, which facilitates the insertion and translocation of almost all different preproteins (Pfanner and Neupert, 1987; Pfaller et al., 1988; Kiebler et al., 1990; Söllner et al., 1992). These four components as well as preproteins accumulated at the GIP are not degraded by proteases added to isolated mitochondria. The protease treatment leaves the GIP site intact as it does not affect the further transport of the accumulated preproteins to the inner membrane (Pfanner and Neupert, 1987; Pfanner et al., 1987b; Pfaller et al., 1988). Preproteins accumulated at the GIP expose portions to the intermembrane space, indicating that the GIP mediates the translocation of preproteins across the outer membrane (Rassow and Pfanner, 1991).

What then is the function of MOM22, the seventh component of the receptor complex? Since MOM22 is known to be exposed on the surface of the outer membrane (Kiebler et al., 1990), it may be expected that it has a function in an early step of translocation. One might speculate that a component is needed for the transfer of preproteins from the surface-exposed receptors MOM19 and MOM72 to the membrane-embedded components of the GIP. We thus investigated the structure and function of MOM22. MOM22 has domains both in the cytosol and in the inter- 
A

$-198$

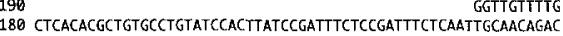

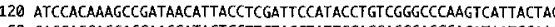

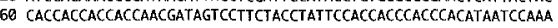

1 ATGGTTCAGCTTACCGAGGTCGAGAGGAGCACTTCCAGCAGCCGCAGGTGGGCCTGAG 1 M V Q L T T V E D E H F Q Q P Q V G P E

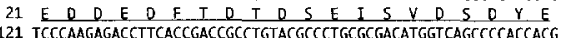
121 TCCCAAGAGACCTTCACGGACCGCCTGTACGCCCTGCGGGACATGGTCAGCCCCACCACG

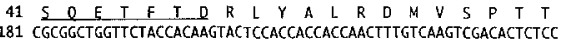
181 CGCGGCTGGTTCTACCACAAGTACTCCACCACCACCAACTTGGTCAGGTCGCACTCTCC

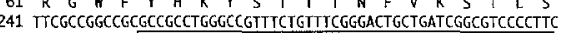

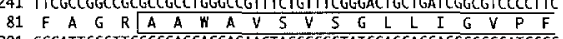
301 GCCATTGCCTICGCGAGGACCAGAACTACGCCGCTATGGAGCAGGAGGCGGGCAIGGGC 101 A I A F A E D Q N Y A A M E D EARMR 361 GAGCTTGGGTCTGATGTTCTCACTGGTGGTGGTGAGGGGCAGGCTGGTACGGCCGAGAAG 121 E L G G S D D V L L T A A G G G E G Q A A G TA A $K$ 141 ACT $L$ A A I G G E G A R P A L

481 GTCTTGGTGTGGAAMATGAAAAACGAAGATGAGCGAGGGATGGATGGTTGTTGTGAACCG 541 GGAGATGTGAAGGGGAGAGAGGGATGGCTGGTGAAAGGGCGGGGGGCTGGAAACCAGCGT 651 CCTTGAACGGATACGCCTACCAGCACCGGGTTCACACTTGACGCAGTCGGATCTGAC

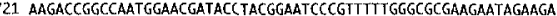
781 aggCCAGCATCGTtAaCCAGCTTACGATGATtATCTCGCCATCCCTCGCATTTGGCGTTT 841 CCCATCTGTCGAAATTCCACTCACTTCTCCCCGCTCAAACACACCGCCACACATJGTATA 901 TTATCTGTTTGGTACTTTIGGGJTGTCCGCCACTTTGCATGGTCGTTGTAATGGTATTCT

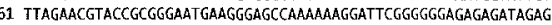
1021 CATTTATAGTCCCGACGAGGACCAAN

Figure 1. cDNA Sequence and Derived Amıno Acid Sequence of MOM22

(A) Nucleotide sequence of the cDNA coding for N. crassa MOM22 and derived amino acid sequence (single letter code). The box indicates the putative membrane-spanning segment (residues 85-105). A cluster of negatively charged amino acid residues in the N-terminal third is underlined. (B) Hydropathy plot according to Kyte and Doolittle (1982). The putative membrane-spanning segment is hatched.

membrane space. Binding of antibodies to the cytosolic domain of MOM22 did not inhibit the interaction of precursors with the receptors MOM19 and MOM72, but blocked the passage of the precursors to the GIP, suggesting that MOM22 acts at a level between receptors and the GIP. We propose that the negatively charged cytosolic domain of MOM22 is needed for facilitating the membrane insertion of positively charged signal sequences.

\section{Results}

\section{Deduced Primary Sequence of MOM22}

As a tool for the identification of MOM22, an antiserum was available that reacted with both Neurospora crassa MOM19 and MOM22 (Kiebler et al., 1990). We screened an N. crassa cDNA library with the antiserum and obtained two groups of clones. One group encoded MOM19 (Schneider et al., 1991); the other group contained an open reading frame coding for a protein of 154 amino acid residues (16.8 kd) (Figure 1A). As shown below, antibodies directed against peptides of the $\mathrm{N}$-terminus or the $\mathrm{C}$-terminus of the deduced sequence selectively recognized MOM22 of the mitochondrial receptor complex and thus identified the CDNA as that for MOM22. The predicted molecular mass of MOM22 is smaller than that of MOM19. Depending on the gel systems used, MOM22 was found to migrate faster or slower than MOM19 (Moczko et al., 1992; see below). The hydropathy plot (Figure 1B) indicated the presence of two hydrophilic portions that are separated by a 21 residue uncharged hydrophobic sequence (residues 85-105) (Figure 1A). The N-terminal region is characterized by an exceptional prevalence of negatively charged residues (18 negative charges and 0 positive charges from residues 6-47) (Figure 1A). A search of the EMBL/GenBank data bases did not reveal a significant homology of MOM22 to any protein on record.

MOM22 Is an Integral Outer Membrane Protein with an Unusual Cluster of Negative Charges in the $\mathrm{N}$-Terminal Domain

To obtain monospecific antibodies against MOM22, peptides corresponding to residues 1-12 and 142-154 of the predicted sequence were synthesized and used to raise antisera in rabbits. Both antibodies, termed anti-MOM22N and anti-MOM22C, specifically recognized a single band among total mitochondrial proteins separated by SDSpolyacrylamide gel electrophoresis (SDS-PAGE) (Figure $2 A$, lanes 4 and 5 ). This band was also labeled by the original anti-MOM19/MOM22 antiserum (Figure 2A, lane 2), but not by an anti-MOM19 antibody (lane 1), identifying it as MOM22. The MOM22 precursor synthesized in vitro in rabbit reticulocyte lysate (Figure $2 \mathrm{~A}$, lane 6 ) had the same apparent size as the mature protein. This was to be expected, as all MOMs identified so far do not have cleavable presequences (Hartl et al., 1989; Baker and Schatz, 1991).

The receptor complex was immunoprecipitated from digitonin-lysed ${ }^{35}$ S-labeled mitochondria with anti-MOM19 antibodies (Kiebler et al., 1990). The immunoprecipitate was then dissociated, and a second immunoprecipitation with specific anti-MOM22 serum was performed under stringent conditions (Figure 2B). MOM22 was thereby selectively precipitated, confirming that it is part of the receptor complex. Similarly, when the receptor complex purified in chemical amounts (Moczko et al., 1992) was immunodecorated with anti-MOM22 antibodies, a selective labeling of MOM22 was found (data not shown).

Thin sections of $\mathrm{N}$. crassa cells were decorated with anti-MOM22 and gold-conjugated anti-rabbit antibodies. 
$\mathbf{A}$
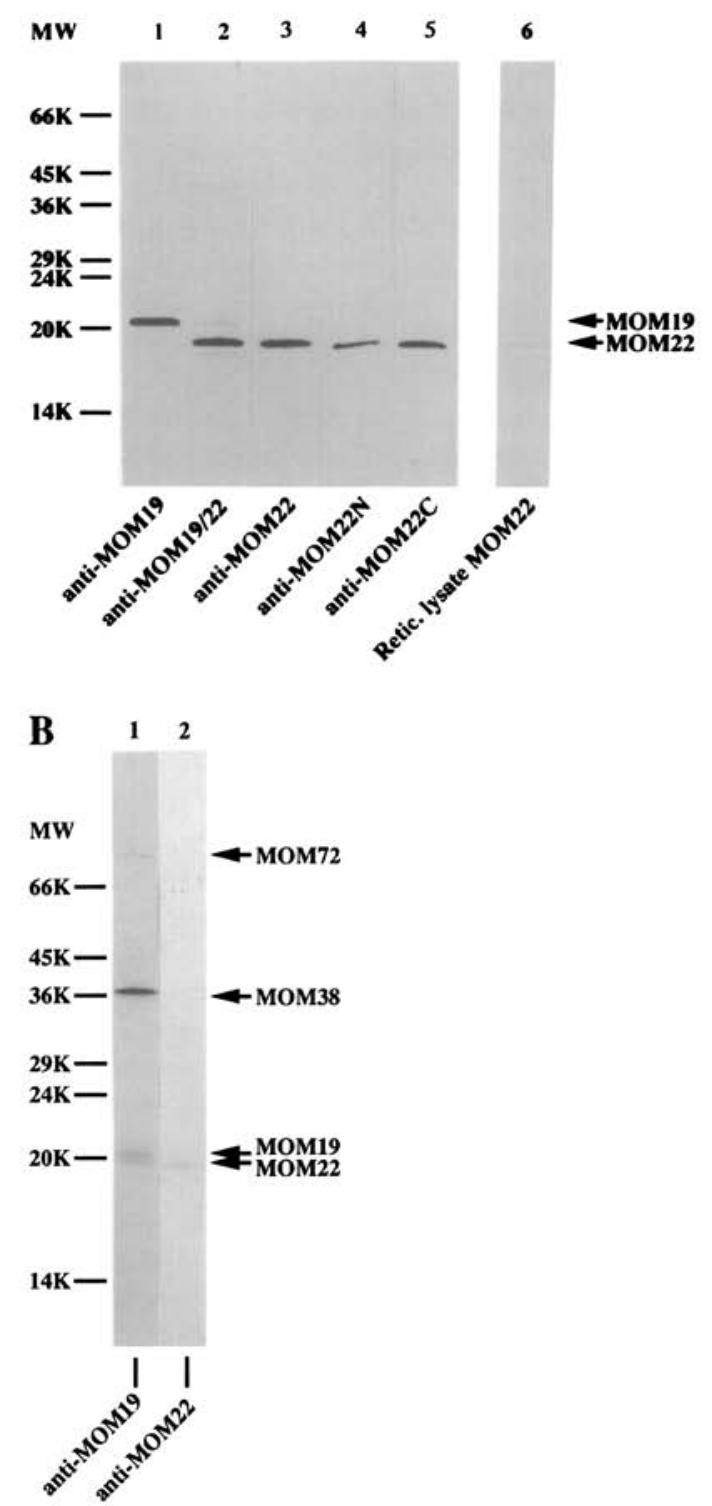

Figure 2. Identification of MOM22 as a Component of the Mitochondrial Receptor Complex by Monospecific Antibodies

(A) Identıfication of MOM22. N. crassa mitochondrial proteins $(50 \mu \mathrm{g}$ per lane) were resolved by SDS-PAGE, electrotransferred to nitrocellulose, and immunodecorated with various antisera (using the ECL Detection System, Amersham): lane 1, anti-MOM19 (Söllner et al., 1989); lane 2, anti-MOM19/MOM22 (Kiebler et al., 1990); lane 3, antiMOM22 that was prepared against a fusion protein between MOM22 (amino acids 1-84) and the maltose-binding protein (see Experimental Procedures), lane 4 , anti-MOM22N (directed against the $\mathrm{N}$-termınus of MOM22); lane 5, anti-MOM22C (directed against the C-terminus of MOM22). In lane 6, MOM22 cDNA was transcribed and translated in reticulocyte lysate in the presence of $\left[{ }^{35} S\right]$ methionıne, and then SDSPAGE, electroblotting, and autoradiography were performed.

(B) Presence of MOM22 in the mitochondrial receptor complex. ${ }^{35} \mathrm{~S}$-labeled mitochondria ( $50 \mu \mathrm{g}$ of protein) were solubilized with $0.5 \%$ digitonin and subjected to immunoprecipitation with anti-MOM19 antibodies prebound to protein A-Sepharose. The immunoprecipitate was dissociated in SDS-containing buffer. One half of the sample was directly subjected to SDS-PAGE (lane 1). The remaining half was diluted 40 -fold in $1 \%(\mathrm{v} / \mathrm{v})$ Triton X-100-SEM buffer, subjected to immunopre-
The gold particles were found at the periphery of the mitochondria (Figures $3 \mathrm{~A}$ and $3 \mathrm{~B}$ ). Furthermore, isolated mitochondria were labeled with anti-MOM22 and gold-conjugated anti-rabbit antibodies prior to embedding and sectioning. This led to decoration of the outer membrane (Figure 3C). A similar result was obtained when antiMOM22N antibodies were used (Figure 3D). AntiMOM22C antibodies, however, did not bind to intact mitochondria; occasionally, we saw a labeling of vesicles (Figure 3E) that may represent inverted outer membranes derived from a few nonintact mitochondria in the preparation. The immunocytochemical results thus suggest that the $\mathrm{N}$-terminus of MOM22 is exposed on the mitochondrial surface and that the C-terminus is located on the intermembrane space side.

The uncharged hydrophobic sequence in the middle of MOM22 is of sufficient length to act as a possible membrane anchor. We tested whether MOM22 was an integral membrane protein by treating mitochondria at alkaline $\mathrm{pH}$ (pH 11.5). By this procedure, soluble and peripheral membrane proteins are extracted, while integral membrane proteins remain in the membrane sheets (Fujiki et al., 1982). MOM22 was indeed fully resistant to an extraction at alkaline $\mathrm{pH}$ (Figure 4A), suggesting that it is an integral membrane protein. Furthermore, MOM22 remained associated with the membranes upon sonication and salt treatment (Figure 4B).

The components of the mitochondrial receptor complex studied so far can be grouped into two classes according to their protease accessibility. The receptors MOM19 and MOM72 are easily degraded by proteases added to intact mitochondria (Söllner et al., 1989, 1990), while the components of the GIP, such as MOM38, are quite protected against proteases (Kiebler et al., 1990; Söllner et al., 1992). In Figure 4C we analyzed the sensitivity of MOM22 in intact mitochondria to various proteases (proteinase $\mathrm{K}$, trypsin, and elastase) and found an intermediate behavior between that of the receptors and MOM38. Treatment with each of the proteases led to degradation of MOM22 to a fragment with an apparent size of $12 \mathrm{kd}$ (Figure $4 \mathrm{C}$ ) that was stable at even high concentrations of protease, unless the outer membrane was opened by detergent prior to the protease treatment (see below). At lower concentrations of proteinase $\mathrm{K}$ and elastase, intermediate-sized fragments of $19 \mathrm{kd}$ and $16 \mathrm{kd}$ were observed (Figure $4 \mathrm{C}$ ).

The topology of MOM22 suggested by the electron microscopy data was confirmed by demonstrating that the $12 \mathrm{kd}$ fragment lacked the $\mathrm{N}$-terminal part. The fragment was recognized by the anti-MOM22C antibody, but not the anti-MOM22N antibody (Figure 4D). It was digested by protease after lysing mitochondria with Triton X-100 or

cipitation (Pfanner and Neupert, 1985) with antı-MOM22 antibodies, and further analyzed as described above (lane 2). The immunoprecipıtation of the receptor complex was performed under the originally described conditions (Kiebler et al., 1990), which led to a coprecipitation, particularly of the "core" components MOM19, MOM22, MOM38, and a fraction of MOM72 (Moczko et al., 1992), suggesting that MOM22 is relatively stably associated with MOM19 and MOM38. 


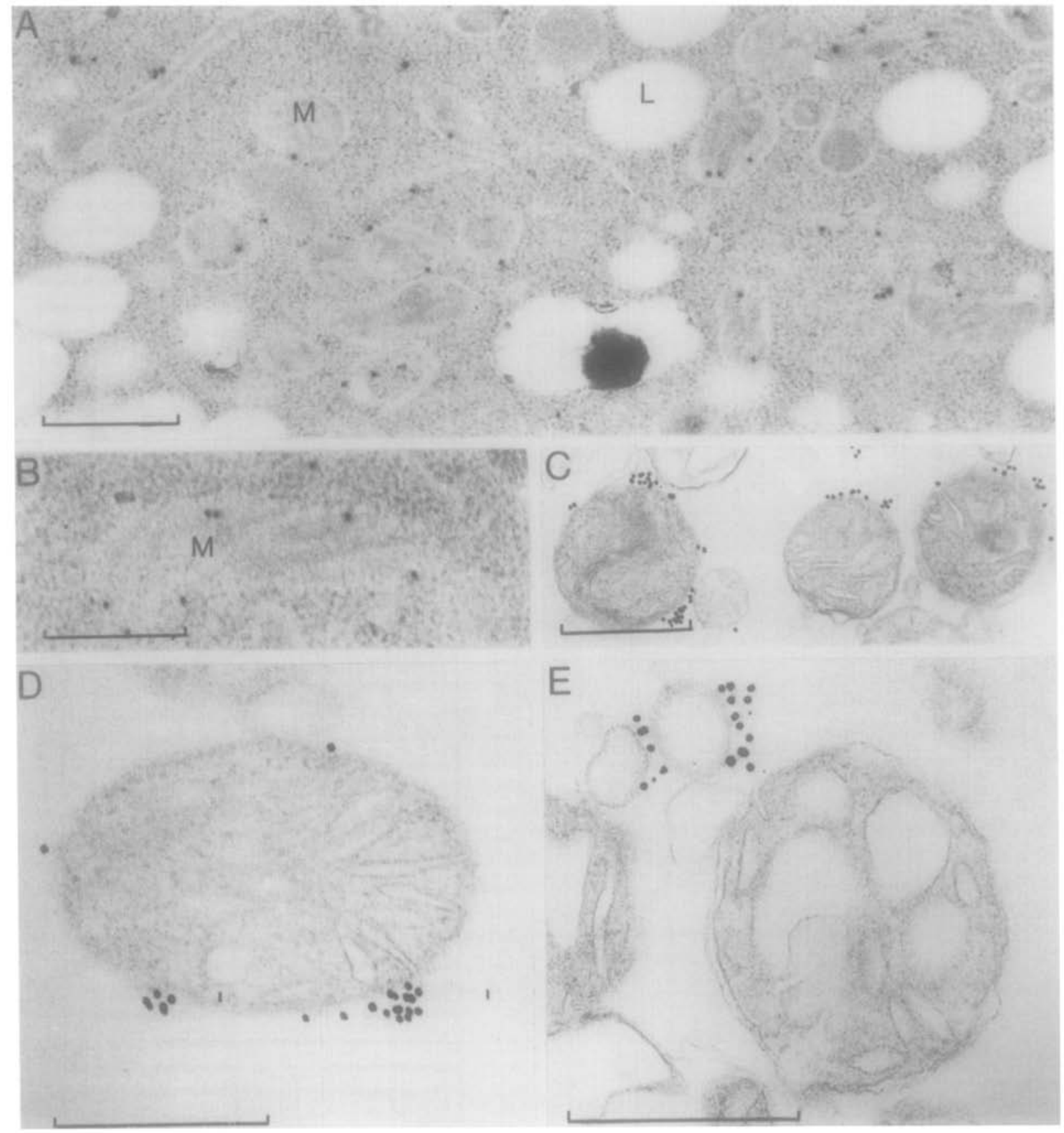

Figure 3. Immunocytochemical Localization of MOM22 to the Mitochondrial Outer Membrane

(A and B) Immunolabeling of ultrathin sections of Lowicryl-embedded N. crassa cells. The sections were incubated with anti-MOM22 antibodies and gold-conjugated goat anti-rabbit antibodies. L, lipid droplet; $M$, mitochondrion.

(C-E) Preembedding labeling of isolated mitochondria using anti-MOM22 antibodies (C), anti-MOM22N antibodies (D), and anti-MOM22C antibodies (E). In (E), intact mitochondria are not specifically labeled with the anti-MOM22C antibodies, yet occasionally small vesicles are labeled that are considered to represent inside-out vesicles of the outer mitochondrial membrane.

The bars represent $0.5 \mu \mathrm{m}$.

upon opening the intermembrane space with digitonin (Figure 4D), excluding the possibility that it possessed an endogenous protease resistance. The protected $12 \mathrm{kd}$ fragment, which is resistant to extraction at alkaline $\mathrm{pH}$ (Figure 4A) or sonication (Figure 4B), thus represents the

\section{C-terminal half of MOM22 including the membrane anchor} sequence.

We conclude that MOM22 is anchored in the outer membrane by a single hydrophobic sequence (residues 85105). The highly negatively charged $\mathrm{N}$-terminal half is obvi- 
A
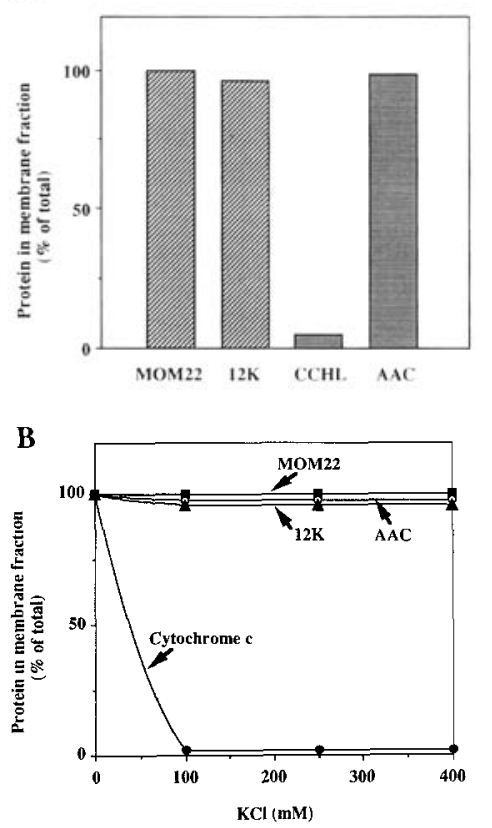

C
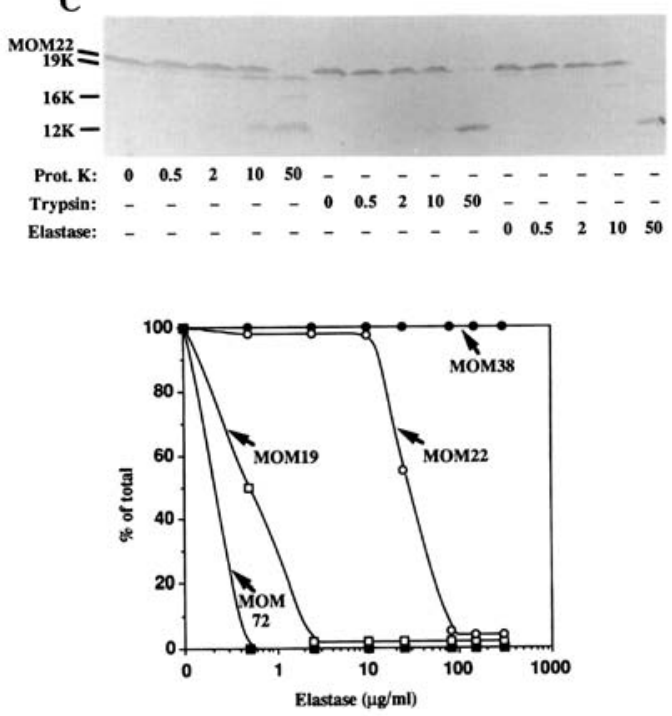

D

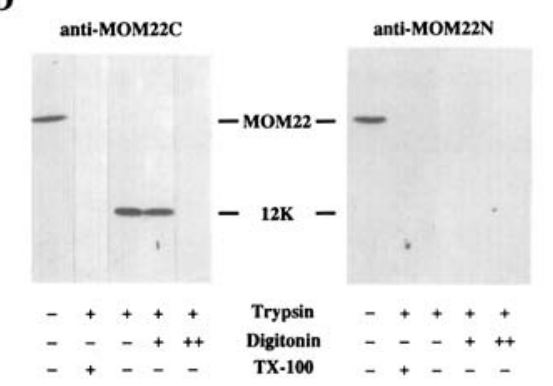

Figure 4. MOM22 Is an Integral Outer Membrane Protein with a Cytosolic Domain and a Domaın in the Intermembrane Space

(A) MOM22 is not extracted from the membranes at $\mathrm{pH} 11.5$. Mitochondria (100 $\mu \mathrm{g}$ of protein) were incubated in $100 \mathrm{mM} \mathrm{Na}_{2} \mathrm{CO}_{3}$ for 30 $\min$ at $0^{\circ} \mathrm{C}$. Separation of pellets and supernatants was performed as described (Hartl et al., 1986) Analysis was by immunodecoration with

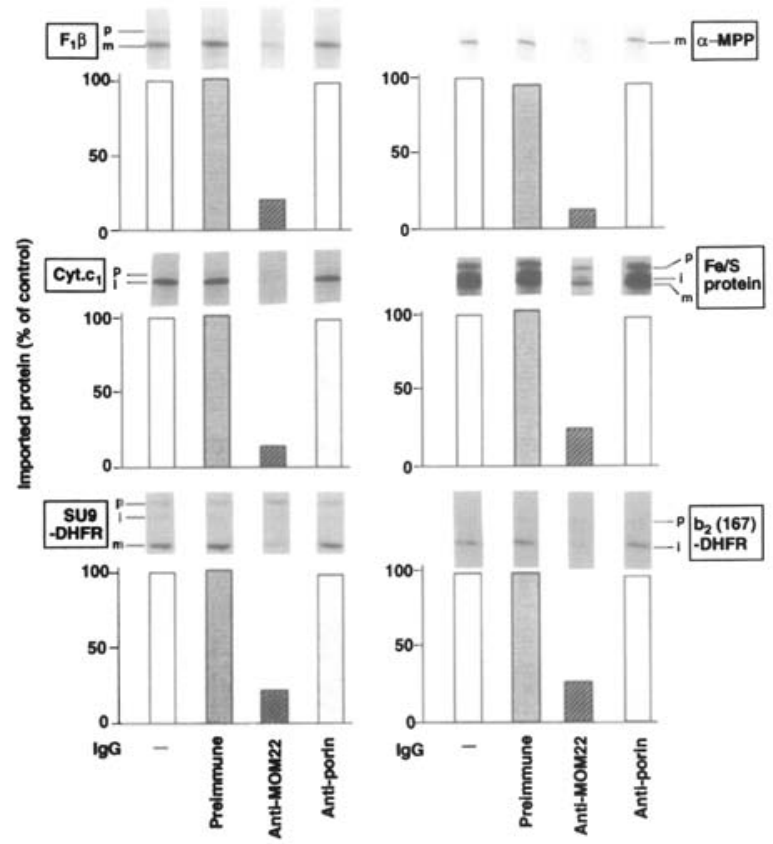

Figure 5. Antibodies against the N-Termınal Domain of MOM22 Inhibit the Import of Preproteins with Cleavable Targeting Sequences

IgGs $(100 \mu \mathrm{g})$ from preimmune serum, antiserum directed against the N-termınal half of MOM22 (anti-MOM22), or antiserum directed against porin were prebound to isolated mitochondria $(12.5 \mu \mathrm{g}$ of proten per lane) (see Experimental Procedures). Mitochondrial preproteins were synthesized in rabbit reticulocyte lysates in the presence of $\left[{ }^{35} \mathrm{~S}\right] \mathrm{methi}$ onine and incubated with the energized mitochondria for $7 \mathrm{~min}$ at $25^{\circ} \mathrm{C}$. Then, a treatment with trypsin $(100 \mu \mathrm{g} / \mathrm{ml})$ was performed for $20 \mathrm{~min}$ at $0^{\circ} \mathrm{C}$. The mitochondria were reisolated and analyzed by SDS-PAGE, fluorography, and laser densitometry. The amount of protein imported in a control sample without IgGs was set to $100 \%$. $F_{1} \beta$, $F_{1}$-ATPase subunit $\beta ; \alpha-M P P, \alpha$ subunit of the matrix-processing peptidase; Cyt. $c_{1}$, cytochrome $c_{1} ; \mathrm{Fe} / \mathrm{S}$ protein, $\mathrm{Fe} / \mathrm{S}$ protein of the $\mathrm{bc}_{1}$ complex; Su9-DHFR, fusion protein between the presequence of $F_{0}$-ATPase subunit 9 and DHFR; $b_{2}(167)$-DHFR, fusion protein between the $\mathrm{N}$-terminal 167 amino acid residues of cytochrome $b_{2}$ and DHFR; $p, i$, and $m$, precursor, intermediate, or mature form of a protein, respectively.

antibodies against MOM22 (12K, a $12 \mathrm{kd}$ fragment of MOM22), cytochrome $\mathrm{c}$ heme lyase ( $\mathrm{CCHL}$; an intermembrane space protein), and the AAC. The total amount of protein in pellet and supernatant was set to $100 \%$ (control).

(B) MOM22 is not released from the membranes by salt and sonication. Mitochondria were sonicated at varıous salt concentrations (Sölliner et al., 1989, 1990). Membranes and supernatants were separated by centrifugation for $60 \mathrm{~min}$ at $166,000 \times \mathrm{g}$ and analyzed as described above. Cytochrome $c$, protein of the intermembrane space.

(C) Protease accessibility of MOM22. Mitochondria ( $50 \mu \mathrm{g}$ of protein per lane) were incubated with proteinase K (Prot. K), trypsin, or elastase as indicated and analyzed with anti-MOM22C antibodies (upper and lower panels) or antibodies directed against MOM19, MOM38, or MOM72 (lower panel). 19K, $16 \mathrm{~K}$, and 12K, fragments of MOM22 of $19 \mathrm{kd}, 16 \mathrm{kd}$, or $12 \mathrm{kd}$, respectively.

(D) The $12 \mathrm{kd}(12 \mathrm{~K})$ fragment of MOM22 is recognized by antiMOM22C, but not by anti-MOM22N antibodies. Mitochondria $(75 \mu \mathrm{g}$ of protein per lane) were incubated with $1 \%$ Triton $X-100$ or digitonin (plus sign, $0.05 \%$; double plus sign, $0.15 \%$; at $0.15 \%$, the intermembrane space is opened [Hartl et al., 1986]) for $3 \mathrm{~min}$ at $0^{\circ} \mathrm{C}$; parallel samples were left untreated. Where indicated, a treatment with trypsin $(50 \mu \mathrm{g} / \mathrm{ml})$ was performed. Analysis was performed by Western blotting with anti-MOM22N or anti-MOM22C antibodies. 


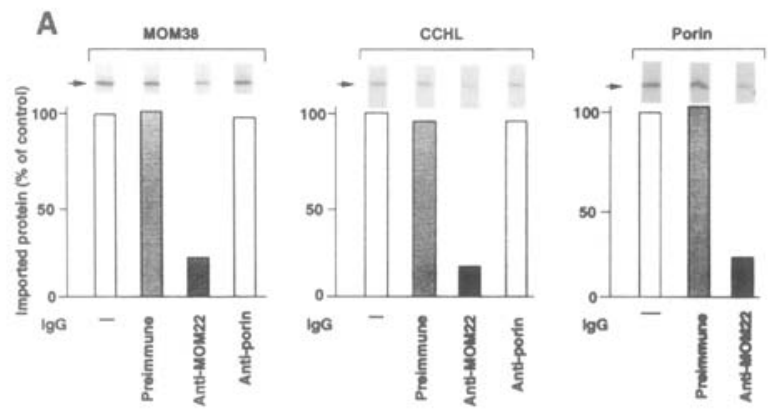

B
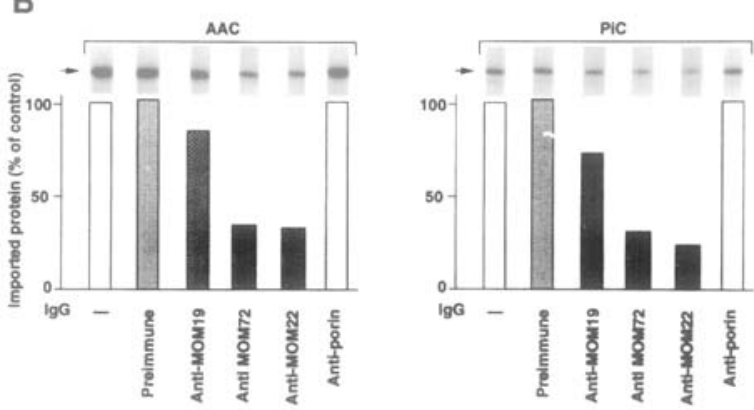

Figure 6. Antibodies against MOM22 Inhibit the Import of Noncleavable Preproteins

(A) Anti-MOM22 antibodies inhibit the import of noncleavable preproteins of the outer membrane (MOM38 and porin) and the intermembrane space (cytochrome $\mathrm{c}$ heme lyase $[\mathrm{CCH} L]$ ). The experiments were performed as described in the legend of Figure 5 except that the import incubation for cytochrome c heme lyase was for $15 \mathrm{~min}$ at $0^{\circ} \mathrm{C}$.

(B) Anti-MOM22 antibodies inhibit the import of noncleavable preproteins of the inner membrane (AAC and phosphate carrier $[\mathrm{PiC}]$ ). The experiments were performed as described in the legend of Figure 5 with the following modifications. In additional samples, the inhibitory effects of antibodies against MOM19 or MOM72 were shown for comparison. After the import reaction, a treatment with proteinase $\mathrm{K}(200$ $\mu \mathrm{g} / \mathrm{ml}$ for AAC; $250 \mu \mathrm{g} / \mathrm{ml}$ for phosphate carrier) was performed. Quantitation was performed as described (Söllner et al., 1990). The arrows point toward the protein band resolved by SDS-PAGE.

ously exposed on the mitochondrial surface, while the C-terminal region is located on the intermembrane space side.

\section{MOM22 is Required for Import of Preproteins along Both Receptor Pathways}

To study the function of MOM22, we obtained an antiserum against its surface-exposed domain. A fusion protein between the $\mathrm{N}$-terminal 84 amino acid residues and the maltose-binding protein was expressed in Escherichia coli and used to raise antibodies in rabbits. The antiserum was monospecific for MOM22 (see Figure 2A, lane 3). We prepared immunoglobulins $\mathrm{G}$ (IgGs) and preincubated isolated mitochondria with the IgGs. Mitochondrial preproteins were synthesized in rabbit reticulocyte lysates in the presence of $\left[{ }^{35} S\right]$ methionine and imported into the isolated energized mitochondria (Figure 5). A series of preproteins with cleavable presequences were tested, including the precursors of matrix proteins $\left(F_{1}-\right.$ ATPase subunit $\beta$, mitochondrial processing peptidase subunit $\alpha$, and a fusion protein between the presequence of $F_{0}$-ATPase subunit 9 and dihydrofolate reductase [DHFR]), inner membrane proteins (cytochrome $c_{1}$ and the $\mathrm{Fe} / \mathrm{S}$ protein of the $\mathrm{bc}_{1}$ complex), and intermembrane space proteins (the fusion protein between the $167 \mathrm{~N}$-terminal amino acid residues of cytochrome $b_{2}$ and DHFR). Control antibodies directed against the major outer membrane protein porin or from preimmune serum had no effect (Figure 5). Furthermore, we analyzed the import of several noncleavable preproteins, such as porin and MOM38 of the outer membrane and cytochrome $c$ heme lyase of the intermembrane space (Figure 6A). The anti-MOM22 antibodies also strongly inhibited the import of these precursors.

All the preproteins tested use MOM19 as their main receptor, and the strong inhibitory effect of the anti-MOM22 antibodies was almost identical to that of anti-MOM19 antibodies (Söllner et al., 1989; Steger et al., 1990). We therefore asked whether anti-MOM22 antibodies would also interfere with import of preproteins that preferentially use MOM72 as an import receptor and are inhibited by antiMOM19 antibodies only to a minor degree (Söllner et al., 1990; Steger et al., 1990). To this end, the import of the precursors of the AAC and the phosphate carrier of the inner membrane were studied. The anti-MOM22 antibodies also strongly inhibited the import of these two precursors (Figure 6B). This inhibition was far higher than that caused by anti-MOM19 antibodies (Figure 6B).

In summary, anti-MOM22 antibodies inhibit the import of both preproteins using MOM19 and preproteins using MOM72 as surface receptors. To exclude the possibility that the observed inhibition was an artifact caused by the divalent nature of the IgGs, we prepared Fab fragments from the anti-MOM22 antibodies and tested their effect on the import of various preproteins (Figure 7). The import of the preproteins was inhibited by the Fab fragments to about the same degree as by the IgGs. As control, we show that Fab fragments against porin had no inhibitory effect.

\section{MOM22 Acts in the Transfer of Preproteins} from Receptors to the GIP

At which stage of the import pathway is MOM22 required? The transport of the AAC across the outer membrane can be divided into two steps (Pfanner et al., 1987b): binding
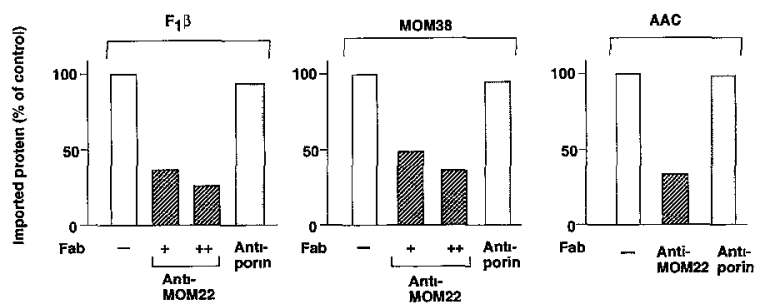

Figure 7. Fab Fragments Directed agaınst MOM22 Inhibit Protein Import

The experiments were performed as described in the legend to Figure 5 except that Fab fragments ( $40 \mu \mathrm{g}$ [plus sign] or $80 \mu \mathrm{g}$ [double plus sign and the other samples]) were used instead of IgGs. 

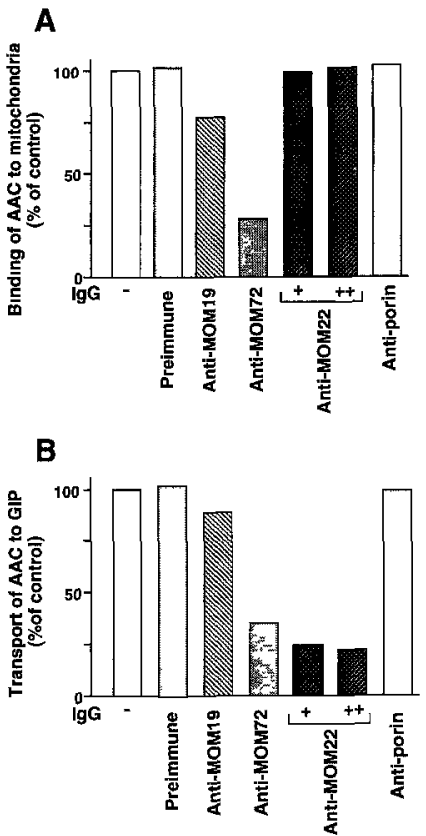

Figure 8. Antibodies against MOM22 Do Not Inhibit Binding to the Receptors, but Inhıbit the Insertion of the AAC into the GIP

(A) Binding of the AAC to the surface receptors is not inhibited by anti-MOM22 antibodies. Mitochondria (12.5 $\mu \mathrm{g}$ of protein) were pretreated with apyrase to deplete ATP and incubated with IgGs as indicated $(60 \mu \mathrm{g}$ [plus sign] or $120 \mu \mathrm{g}$ [double plus sign and the other samples]) and described in Experımental Procedures. Then, the mem. brane potential was dissipated, and the precursor of the AAC was bound to the mitochondria. Analysis was performed as described in the legend of Figure 5 .

(B) Insertion of the AAC into the GIP is inhibited by anti-MOM22 antibodies. Isolated mitochondria were preincubated with IgGs as described above. Transport of the precursor of the AAC to the GIP was performed in the presence of ATP (no apyrase) as well as in the absence of a membrane potential, followed by a treatment with $20 \mu \mathrm{g} /$ $\mathrm{ml}$ proteinase $\mathrm{K}$ as described in Experimental Procedures.

to the surface receptors MOM72 and MOM19 (Söllner et al., 1990, 1992; Steger et al., 1990) and insertion into the outer membrane at the GIP (Pfaller et al., 1988; Söliner et al., 1992). In Figure 8A, accumulation of the precursor of the AAC at the surface receptors was analyzed. Preincubation of mitochondria with antibodies against MOM72 or MOM19 inhibited this binding step; with anti-MOM72 antibodies, the inhibition was about $70 \%$, and with antiMOM19 antibodies it was $15 \%-20 \%$ (Figure $8 \mathrm{~A}$ ), in agreement with the relative contributions of both receptors to the import of the AAC (Steger et al., 1990). Antibodies against MOM22, however, did not show any inhibitory effect on binding (Figure 8A). We conclude that MOM22 is involved in a transport step occurring after the initial binding of precursors to their receptors. We then tested the transport of the AAC into the GIP. Anti-MOM22 antibodies had a strong inhibitory effect on the formation of the GIP intermediate (Figure $8 \mathrm{~B}$ ); the degree of inhibition of this step was similar to that seen with the overall import of the AAC (see Figure 6B).

A similar stage dependence of import inhibition by antiMOM22 antibodies was also observed for the precursor of the phosphate carrier. All together, these data suggest that MOM22 is required for insertion of preproteins into the GIP.

\section{Discussion}

We have characterized MOM22, a component of the mitochondrial receptor complex, and have provided evidence that it is a functional linker between the mitochondrial surface receptors and the GIP in the outer membrane. MOM22, with its 154 amino acid residues, can be structurally divided into three parts: the $\mathrm{N}$-terminal half on the cytosolic side of the outer membrane, an uncharged transmembrane segment, and the hydrophilic C-terminal domain on the intermembrane space side. MOM22 thus has an inverted orientation in comparison with that of MOM19 or MOM72, which exposes the C-terminus to the cytosol. The most prominent characteristic of MOM22 is the presence of a cluster of 18 negative charges (with no positive charge) in the cytosolic domain.

Antibodies directed against MOM22 inhibited the import of all preproteins analyzed that use the mitochondrial receptor complex. This is in contrast with antibodies directed against the receptors MOM19 or MOM72, which showed different inhibitory effects on different subclasses of preproteins. It may be argued that the antibodies against MOM22 unspecifically block the surface of the mitochondrial receptor complex. This can be excluded on the basis of the following observations. First, Fab fragments were found to exert the same inhibitory effect as divalent antibodies; second, the anti-MOM22 antibodies did not interfere with the binding of the preproteins to their receptors.

It is the subsequent step, the transfer of preproteins into the GIP, that requires MOM22. The import pathways via both receptors MOM19 and MOM72 appear to converge at MOM22. Here the preprotein with its positively charged signal sequence must insert into the translocation machinery of the outer membrane. We propose that the cytosolic domain of MOM22 facilitates the entry of preproteins into the translocation pore, in cooperation with receptors and components of the GIP.

Mitochondrial targeting signals have the potential to form amphipathic $\alpha$ helices in which the positively charged amino acid residues and the hydrophobic residues are facing opposite sites of the helix (Roise et al., 1986; von Heijne, 1986). It is tempting to speculate that the cytosolic domain of MOM22, with its abundant negative charges, provides a surface for the transient binding of the positively charged aspect of the signal sequences. After the initial recognition by the receptor MOM19 or MOM72, the signal sequences would be presented to MOM22. One may further speculate that the conformation of the signal acquired upon this interaction with MOM22 renders the preprotein competent for insertion into the translocation pore.

Translocation of preproteins across membranes has also been characterized in considerable detail with the endoplasmic reticulum and the plasma membrane of $E$. coli, and quite a number of components of the transport machineries have been identified and sequenced (reviewed in Wickner et al., 1991; Rapoport, 1992; Sanders 
and Schekman, 1992). The signal/leader sequences of preproteins translocated into the endoplasmic reticulum or out of $\mathrm{E}$. coli are quite different from the signal sequences of mitochondrial preproteins. They are characterized by a hydrophobic core usually preceded by a single positive charge. Thus, a highly negatively charged surface for facilitating insertion into a translocation pore may not be needed. In fact, of the components of the endoplasmic reticulum or the $\mathrm{E}$. coli transport machineries identified so far, none has a domain that is as negatively charged as the N-terminus of MOM22. However, a situation comparable to that in the mitochondrial outer membrane may exist in the chloroplast envelope. Transit sequences of chloroplast preproteins resemble mitochondrial signal sequences in the prevalence of positive charges (Keegstra and von Heijne, 1992). It will be interesting to see whether a component similar to or equivalent to MOM22 exists in the chloroplast outer envelope membrane.

\section{Experimental Procedures}

\section{Isolation of Mitochondria}

N. crassa wild-type $74 \mathrm{~A}$ was grown and harvested as described (Schleyer et al., 1982). For labeling with ${ }^{35} \mathrm{~S}, 5 \mathrm{mCi}$ l $^{35}$ S]sulfate (Amersham) was added per liter of culture (growth medium containing 0.08 $\mathrm{mM}$ unlabeled sulfate). Mitochondria were isolated as described (Schleyer et al., 1982) and resuspended in SEM buffer $(250 \mathrm{mM}$ sucrose, $1 \mathrm{mM}$ EDTA, $10 \mathrm{mM}$ MOPS-KOH [pH 7.2]) at a final protein concentration of $5 \mathrm{mg} / \mathrm{ml}$.

\section{Isolation and Sequencing of MOM22 CDNA}

Antibody screening was performed with a size-fractionated $\lambda \mathrm{gt} 11 \mathrm{li}-$ brary of N. crassa cDNA (Young and Davis, 1983; Schneider et al., 1990). The resulting CDNA clones were subcloned into the EcoRI site of pGEM4 (Promega Biotec; Melton et al., 1984; Söllner et al., 1990) and pUEX (Bressan and Stanley, 1987). Supercoil sequencing was performed with denatured plasmids (Chen and Seeburg, 1985) according to the dideoxy chain termination method (Sanger et al., 1977) using Sequenase (a modified T7 DNA polymerase, U. S. Biochemical; Tabor and Richardson, 1987) and ${ }^{35}$ S-labeled dATP (Amersham). To isolate a full-length cDNA clone, the $\lambda$ gt 11 library of $N$. crassa cDNA was screened using the radiolabeled cDNA insert (Rigby et al , 1977) identified from the first screen. The full-length CDNA was subcloned into PGEM4 and sequenced using MOM22-specific cDNA primers and subcloned restriction fragments of the CDNA.

Expression of the N-Terminal Domain of MOM22 in E. coli Using two MOM22-spectic CDNA primers, one for the coding strand including the start ATG (5'-GCG AAT TCC ATG GTT CAG CTT ACC GAG-3', introducing a Ncol site at the ATG), the other for the complementary strand in the reverse orientation ( 3 '-GCG GCC GCT TCC TCT CAC-5), the CDNA from nucleotides 191-441 (coding for the first 84 amino acid residues of MOM22) was amplified by polymerase chain reaction (Saiki et al., 1988; Innis et al., 1988). The resulting polymerase chain reaction fragment was digested with $\mathrm{Ncol}$ and ligated to an $\mathrm{Ncol}-$ EcoRI-linearized maltose-fusion protein vector, pMALcRI (New England Biolabs; Maina et al., 1988). The resulting linearized fragment was treated with the Klenow fragment of E. coli DNA polymerase I (Boehringer Mannheim; Sambrook et al., 1989) for $15 \mathrm{~min}$ at $37^{\circ} \mathrm{C}$ in the presence of $100 \mu \mathrm{M}$ deoxynucleotides (Boehringer Mannheim) and Klenow buffer ( $10 \mathrm{mM} \mathrm{MgSO}{ }_{4}, 1 \mathrm{mM}$ dithiothreitol, $50 \mathrm{mM}$ Tris- $\mathrm{HCl}$ $[\mathrm{pH} 7.2])$, ligated again, and transformed (Hanahan, 1983) into the $E$. coll strain TB1 (New England Biolabs).

Expression of the resulting fusion protein between the $\mathrm{N}$-terminal half of MOM22 and the maltose-binding protein was induced for $2 \mathrm{hr}$ at $37^{\circ} \mathrm{C}$ with $1 \mathrm{mM}$ isopropyl $\beta$-D-thiogalactopyranoside (Boehringer Ingelherm). The cells were harvested by centrifugation, incubated with water-solved lysozyme and DNAase $(4 \mathrm{mg} / \mathrm{ml}$ and $1 \mathrm{mg} / \mathrm{ml}$, respec- tively; Serva-Boehrınger Mannheim) for $10 \mathrm{~min}$ at $0^{\circ} \mathrm{C}$, frozen and thawed several times, and mixed with 2-fold sample buffer $(120 \mathrm{mM}$ Tris- $\mathrm{HCl}[\mathrm{pH} 6.8], 4 \%[\mathrm{w} / \mathrm{v}] \mathrm{SDS}, 20 \%[\mathrm{v} / \mathrm{v}]$ glycerol, $0.04 \%[\mathrm{w} / \mathrm{v}]$ bromophenol blue, $2 \%$ [v/v] 2-mercaptoethanol) (Sambrook et al., 1989). After SDS-PAGE, the proteins were transferred to nitrocellulose (semidry electrophoretic transfer for 1-2 hr at $200 \mathrm{~mA}$; KysheAndersen, 1984) in blot buffer (20 mM Tris, $150 \mathrm{mM}$ glycine, $0.02 \%$ SDS, and $20 \%$ methanol). The band reacting with anti-MOM22 antibody was excised and used for generation of antibodies.

\section{Raising of Antisera, Preparation of IgGs and Fab Fragments,} and Immunoprecipitation

Antisera were raised in rabbits against chemically synthesized oligopeptides that were coupled to keyhole limpet hemocyanin (Harlow and Lane, 1988) or against protein expressed in E. coli. The complement was heat inactivated $\left(20 \mathrm{~min}\right.$ at $\left.56^{\circ} \mathrm{C}\right)$, and IgGs were prepared using protein A-Superose column chromatography (Pharmacia). Bound IgGs were eluted with $0.1 \mathrm{M}$ citrate $(\mathrm{pH} 3.0)$, neutralized with $2 \mathrm{M}$ Tris base $(\mathrm{pH} 8.8)$, dialysed against water, lyophilized, and dissolved in SEM buffer at a protein concentration of $5-50 \mathrm{mg} / \mathrm{ml}$. Aliquots were frozen at $-20^{\circ} \mathrm{C}$.

IgGs were digested with papain according to Mage (1981). Fab fragments were separated from IgGs and Fc fragments by using a protein A-Superose column. Fab fragments were dialysed agaınst water, lyophilized, and dissolved in SEM buffer at a protein concentration of $5-50 \mathrm{mg} / \mathrm{ml}$. Aliquots were frozen at $-20^{\circ} \mathrm{C}$.

For immunoprecipitation of the receptor complex, mitochondria $(1$ $\mathrm{mg} / \mathrm{ml}$ protein) were lysed in digitonin buffer $(0.5 \%[\mathrm{w} / \mathrm{v}]$ digitonin, $3 \%$ [w/v] bovine serum albumin [BSA], $100 \mathrm{mM} \mathrm{NaCl}, 1 \mathrm{mM}$ phenylmethylsulfonyl fluoride in SEM buffer) for $15 \mathrm{~min}$ at $0^{\circ} \mathrm{C}$, followed by centrifugation for $15 \mathrm{mIn}$ at $25,000 \times \mathrm{g}$. This extract was incubated with protein A-Sepharose carrying specific antibodies in digitonin buffer for 90 $\min$ at $0^{\circ} \mathrm{C}$. The immunoprecipitates were washed in digitonin buffer (without BSA). Dissociation of the immunoprecipitates was performed by adding sample buffer, followed by SDS-PAGE and fluorography.

\section{Mitochondrial Binding and Import of Preproteins In Vitro}

Specific messenger RNA transcripts coding for preproteins were synthesized with SP6 polymerase (Melton et al., 1984) from pGEM4 plasmids and translated in rabbit reticulocyte lysate (Pelham and Jackson, 1976) in the presence of $\left[{ }^{35} S\right]$ methionine (Amersham). Postribosomal supernatants were prepared and supplemented as described (Zimmermann and Neupert, 1980).

IgGs or Fab fragments were incubated with isolated mitochondria (12.5 $\mu \mathrm{g}$ of protein per lane) in SEM or BSA buffer ( $250 \mathrm{mM}$ sucrose, $3 \%$ [w/V] BSA, $80 \mathrm{mM} \mathrm{KCl}, 5 \mathrm{mM} \mathrm{MgCl} 2,10 \mathrm{mM}$ MOPS-KOH [pH 7.2]) for $35 \mathrm{~min}$ at $4^{\circ} \mathrm{C}$ in a final volume of $50 \mu \mathrm{l}$. Import reactions contained, in addition to the pretreated mitochondria, $8 \mathrm{mM}$ potassium ascorbate and $0.2 \mathrm{mM}$ tetramethylphenylenediamine, $10 \mathrm{mM}$ unlabeled methionine, $1-10 \mu \mathrm{l}$ of reticulocyte lysate, and BSA buffer up to a final volume of $200 \mu \mathrm{l}$. All reactions were made chemically identical by adding the same volume of reagent-free solvent to the control samples. Incubation was usually performed for $7 \mathrm{~min}$ at $25^{\circ} \mathrm{C}$, except for cytochrome $\mathrm{c}$ heme lyase $\left(15 \mathrm{~min}\right.$ at $\left.0^{\circ} \mathrm{C}\right)$. The analysis was thereby performed in the linear range of the import kinetics of the respective precursors (Pfanner et al., 1987a; Söllner et al., 1989, 1990; Lill et al., 1992).

For binding of the AAC to the mitochondrial surface, reticulocyte lysate and mitochondria were separately pretreated with apyrase (5 $\mathrm{U} / \mathrm{ml}$; Sigma grade VIII; Pfanner and Neupert, 1986) for $15 \mathrm{~min}$ at $25^{\circ} \mathrm{C}$ or $25 \mathrm{~min}$ at $4^{\circ} \mathrm{C}$, respectively. The binding reaction was performed in the presence of antimycin $\mathrm{A}(8 \mu \mathrm{M})$, oligomycin $(20 \mu \mathrm{M})$, and valinomycin $(0.5 \mu \mathrm{M})$ (Sigma; Pfanner et al., 1987b; Pfaller et al., 1988) to dissipate the membrane potential. The insertion of the AAC into the outer membrane (the GIP) was performed in the absence of a membrane potential but in the presence of ATP (no apyrase treatment) (Pfanner and Neupert, 1987). The mitochondria were reisolated, washed with SEM buffer, and treated with proteinase $\mathrm{K}$ for $20 \mathrm{~min}$ at $0^{\circ} \mathrm{C}(200 \mu \mathrm{g} / \mathrm{ml}$ for imported AAC; $20 \mu \mathrm{g} / \mathrm{ml}$ for AAC at the GIP; mock treatment for AAC at the receptor stage) (Söllner et al., 1991). The mitochondria were reisolated and subjected to SDS-PAGE, fluorography, and laser densitometry (Söllner et al., 1991). 
Protease Treatment of Mitochondria and Western Blotting Mitochondria ( $1 \mathrm{mg} / \mathrm{ml}$ protein) were treated with protease (added from a stock solution of $2.5 \mathrm{mg} / \mathrm{ml}$ in SEM buffer). After $20 \mathrm{~min}$ at $0^{\circ} \mathrm{C}$, the protease was inactivated by addition of $1 \mathrm{mM}$ phenylmethylsulfonyl fluoride and, in the case of trypsin, a 20 -fold weight excess of soybean trypsin inhibitor and incubated for $10 \mathrm{~min}$ at $0^{\circ} \mathrm{C}\left(15 \mathrm{~min}\right.$ at $25^{\circ} \mathrm{C}$ In the case of elastase). Mitochondria were then reisolated, and the proteins were separated by SDS-PAGE and transferred to nitrocellulose (semidry electrophoretic transfer). The nitrocellulose was incubated in $5 \%$ milk powder and Tris-buffered saline (TBS) ( $150 \mathrm{mM} \mathrm{NaCl}$, $10 \mathrm{mM}$ Tris [pH 7.2]) for $20 \mathrm{~min}$ at $25^{\circ} \mathrm{C}$. Then, the first antiserum was added (dilution 1:1000 in TBS-5\% milk powder; $1.5 \mathrm{hr}$ at $25^{\circ} \mathrm{C}$ ). After extensive washing in TBS and TBS- $0.1 \%$ Triton X-100, the blot was incubated with an enzyme-coupled antibody directed against rabbit IgGs. Two methods were applied: horseradish peroxidase or alkaline phosphatase (both 1:1000 in TBS-5\% mlk powder; $1 \mathrm{hr}$ at $25^{\circ} \mathrm{C}$ ). After extensive washing in TBS and TBS- $0.1 \%$ Triton X-100, color reaction was performed for alkaline phosphatase with bromochloroindolyl phosphate and nitro blue tetrazolium in $100 \mathrm{mM} \mathrm{NaCl}, 5 \mathrm{mM}$ $\mathrm{MgCl}_{2}, 100 \mathrm{mM}$ Tris- $\mathrm{HCl}(\mathrm{pH} 9.5)$ for $1-5 \mathrm{~min}$ at $25^{\circ} \mathrm{C}$; in the case of horseradish peroxidase, the reaction was performed etther with diamınobenzıdine and $\mathrm{H}_{2} \mathrm{O}_{2}(0.1 \%)$ in $50 \mathrm{mM}$ Tris- $\mathrm{HCl}(\mathrm{pH} \mathrm{7.5)}$ or with the ECL Western Blotting System (Amersham).

\section{Electron Microscopy}

For immunocytochemıstry, hyphae were fixed in $3 \%(\mathrm{v} / \mathrm{v})$ glutaraldehyde in $0.1 \mathrm{M}$ cacodylate buffer $(\mathrm{pH} 7.2)$ for $60 \mathrm{~min}$ at $0^{\circ} \mathrm{C}$, dehydrated in a graded ethanol series, and embedded in Lowidryl $\mathrm{K}_{4} \mathrm{M}$. Immunolabeling was performed on ultrathin Lowicryl sections using monospecific antibodies against MOM22 and gold-conjugated goat antirabbit antibodies according to the instructions of the manufacturer (Amersham).

For preembedding labeling, $50 \mu \mathrm{l}$ of antiserum, $50 \mu \mathrm{l}$ of isolated mitochondria ( $1 \mathrm{mg} / \mathrm{ml}$ protein in SEM buffer), and $100 \mu$ lof buffer $A(8$ $\mu l$ of a 10-fold concentrated phosphate-buffered saline-glycine stock solution in $92 \mu$ l of SEM buffer [final concentration of glycine, $8 \mathrm{mM}$ ]) were mixed. Upon incubation for $1 \mathrm{hr}$ at $0^{\circ} \mathrm{C}$, the organelles were reisolated, washed twice in buffer $A$, and resuspended in $500 \mu l$ of buffer $A$ containing gold-conjugated goat anti-rabbit antibodies (dilutIon 1:10). After incubation for $1 \mathrm{hr}$ at $0^{\circ} \mathrm{C}$, the organelles were again reisolated, washed twice in buffer $\mathrm{A}$, and fixed in $3 \%(\mathrm{v} / \mathrm{v})$ glutaraldehyde in $0.1 \mathrm{M}$ sodium cacodylate buffer $(\mathrm{pH} 7.2)$ for $30 \mathrm{~min}$ at $0^{\circ} \mathrm{C}$ Postfixation was in a mixture of $0.5 \%(\mathrm{w} / \mathrm{v}) \mathrm{OsO}_{4}$ and $2.5 \%(\mathrm{w} / \mathrm{v})$ $\mathrm{K}_{2} \mathrm{Cr}_{2} \mathrm{O}_{7}$ in the same cacodylate buffer for $1 \mathrm{hr}$ at room temperature. The samples were posthydrated in $1 \%(\mathrm{w} / \mathrm{v})$ aqueous uranyl acetate for 8-16 hr, dehydrated in a graded ethanol series, and embedded in Epon 812. Ultrathin sections were cut with a diamond knife and examined in a Philips EM 300.

\section{Acknowledgments}

The first two authors equally contributed to this work. We thank $M$. Veenhuis for valuable advice on the electron microscopy experiments; T. Söllner, J. Kirchner, K.-P. Künkele, H. Martin, M. Moczko, K. Dietmeier, and V. Zara for help with some experiments; and R. Stuart for discussions. We are grateful to U. Hanemann, A. Weinzierl, and I. Keizer-Gunnink for expert technical assistance and to W. Fritz for help with the illustrations. This work was supported by the Sonderforschungsbereich 184 (München) and the Sonderforschungsbereich 206 (Freiburg), the Fonds der Chemischen Industrie, a fellowshıp from the Boehringer Ingelheim Fonds (to M. K.), and a long-term European Molecular Biology Organization fellowship (to I. J. v. d. K.).

Received March 22, 1993; revised May 24, 1993.

\section{References}

Alberts, B., and Miake-Lye, R. (1992). Unscrambling the puzzle of biological machines: the importance of the details. Cell 68, 415-420. Baker, K. P., and Schatz, G. (1991). Mitochondrial proteins essential for viability mediate protein import into yeast milochondria. Nature 349, 205-208.
Baker, K. P., Schaniel, A., Vestweber, D., and Schatz, G. (1990). A yeast mitochondrial outer membrane protein essential for protein import and cell viability. Nature 348, 605-609.

Becker, K., Guiard, B., Rassow, J., Söllner, T., and Pfanner, N. (1992). Targeting of a chemically pure preprotein to mitochondria does not require the addition of a cytosolıc signal recognition factor. J. Biol. Chem. 267, 5637-5643.

Bressan, G. M., and Stanley, K. K. (1987). pUEX, a bacterial expression vector related to $\mathrm{pEX}$ with universal host specificity. Nucl. Acıds Res. 15, 10056.

Chen, E. J., and Seeburg, P. H. (1985). Supercoil sequencing: a fast and simple method for sequencing plasmid DNA. DNA 4, 165-170.

Fujikı, Y., Hubbard, A. L., Fowler, S., and Lazarow, P. B. (1982). Isolation of intracellular membranes by means of sodium carbonate treatment: application to endoplasmic reticulum. J. Cell Biol. 93, 97-102. Hanahan, D. (1983). Studies on transformation of Escherichia coli with plasmids J. Mol. Biol. 166, 557-580.

Harlow, E., and Lane, D. (1988). Antibodies: A Laboratory Manual (Cold Spring Harbor, New York: Cold Spring Harbor Laboratory Press). Hartl, F.-U., Schmidt, B., Wachter, E., Weiss, H., and Neupert, W. (1986). Transport into mitochondria and intramitochondrial sorting of the $\mathrm{Fe} / \mathrm{S}$ protein of ubiquinol-cytochrome $\mathrm{c}$ reductase. Cell $47,939-$ 951.

Hartl, F.-U., Pfanner, N., Nicholson, D. W., and Neupert, W. (1989). Mitochondrial protein import. Biochim. Biophys. Acta 988, 1-45.

Hase, T., Müller, U., Riezman, H., and Schatz, G. (1984). A 70-kd protein of the yeast mitochondrial outer membrane is targeted and anchored via its extreme amino terminus. EMBO J. 3, 3157-3164.

Hines, V., and Schatz, G. (1993). Precursor binding to yeast mitochondria: a general role for the outer membrane protein Mas70p. J. Biol. Chem. 268, 449-454.

Hines, V., Brandt, A., Griffiths, G, Horstmann, H., Brütsch, H., and Schatz, G. (1990). Protein import into yeast mitochondria is accelerated by the outer membrane protein MAS70. EMBO J. 9, 3191-3200.

Innis, M. A., Myambo, K. B., Gelfand, D. H., and Brow, M. A. D. (1988). DNA sequencing with Thermus aquaticus DNA polymerase and direct sequencing of polymerase chain reaction-amplified DNA. Proc. Natt. Acad. Sci. USA 85, 9436-9440.

Keegstra, K., and von Heijne, G. (1992). Transport of proteins into chloroplasts. In Cell Organelles, R. G. Herrmann, ed. (Vienna: Springer-Verlag), pp. 353-370.

Kiebler, M., Pfaller, R., Söllner, T., Griffiths, G., Horstmann, H., Pfanner, N., and Neupert, W. (1990). Identification of a mitochondrial receptor complex required for recognition and membrane insertion of precursor proteins. Nature $348,610-616$.

Kyshe-Andersen, J. (1984). Electroblotting of multiple gels: a simple apparatus without buffer tank for rapid transfer of proteins from polyacrylamide to nitrocellulose. J. Biochem. Biophys. Meth. 10, 203-207.

Kyte, J., and Doolittle, R. F. (1982). A method for displaying the hydrophobic character of a protein. J. Mol. Biol. 157, 105-132.

Lill, R., Stuart, R. A., Drygas, M. E., Nargang, F. E., and Neupert, W. (1992). Import of cytochrome $c$ heme lyase into mitochondria: a novel pathway into the intermembrane space. EMBO J. 11, 449-456.

Mage, M. G. (1981) Preparation of Fab fragments from IgGs of different animal species. Meth. Enzymol. 73, 142-150.

Maina, C. V., Riggs, P. D., Grandea, A. G., III, Slattko, B. E., Moran, L. S., Tagliamonte, J. A., McReynolds, L. A., and Guan, C. D. (1988). An Escherichia coli vector to express and purify foreign proteins by fusion to and separation from maltose-binding protein. Gene 74, 365373.

Melton, D. A., Krieg, P. A., Rebagliati, M. R., Maniatis, T., Zinn, K., and Green, M. R (1984). Efficient in vitro synthesis of biologically active RNA and RNA hybridization probes from plasmids containing a bacteriophage SP6 promoter. Nucl. Acids Res. 12, 7035-7056.

Moczko, M., Dietmeier, K., Söllner, T., Segui, B., Steger, H. F., Neupert, W., and Pfanner, N. (1992). Identification of the mitochondrial 
receptor complex in Saccharomyces cerevisiae. FEBS Lett. 310, 265268.

Neupert, W., Hartl, F.-U., Craig, E. A., and Pfanner, N. (1990). How do polypeptides cross the mitochondrial membranes? Cell $63,447-$ 450.

Pelham, H. R. B., and Jackson, R. J. (1976). An efficient mRNAdependent translation system from retıculocyte lysates. Eur. J. Biochem. 67, 247-256.

Pfaller, R., Steger, H. F., Rassow, J., Pfanner, N., and Neupert, W. (1988). Import pathways of precursor proteins into mitochondria: multiple receptor sites are followed by a common membrane insertion site. J. Cell Biol. 107, 2483-2490.

Pfanner, N., and Neupert, W. (1985). Transport of protenns into mitochondria: a potassium diffusion potential is able to drive the import of ADPIATP carrier. EMBO J. 4, 2819-2825.

Pfanner, N., and Neupert, W. (1986). Transport of F -ATPase subunit $\beta$ into mitochondria depends on both a membrane potential and nucleosıde triphosphates. FEBS Lett. 209, 152-156.

Pfanner, N., and Neupert, W. (1987). Distinct steps in the import of ADPIATP carrier into mitochondria. J. Biol. Chem. 262, 7528-7536.

Pfanner, N., Müller, H., Harmey, M. A., and Neupert, W. (1987a). Mitochondrial protein import: involvement of the mature part of a cleavable precursor protein in the binding to receptor sites. EMBO J. 6, 34493454.

Pfanner, N., Tropschug, M., and Neupert, W. (1987b). Mitochondrial protein import: nucleoside triphosphates are involved in conferring import-competence to precursors. Cell $49,815-823$.

Pfanner, N., Rassow, J., Guiard, B., Söllner, T., Hartl, F.-U., and Neupert, W. (1990). Energy requirements for unfolding and membrane translocation of precursor proteins during import into mitochondria J. Biol. Chem. 265, 16324-16329.

Rapoport, T. A. (1992). Transport of proteins across the endoplasmic reticulum membrane. Science 258, 931-936.

Rassow, J., and Pfanner, N. (1991). Mitochondrial preproteins en route from the outer membrane to the inner membrane are exposed to the Intermembrane space. FEBS Lett. 293, 85-88.

Rigby, P.W. J., Dieckman, M., Rhodes, C., and Berg, P. (1977). LabelIng deoxyribonucleic acıd to high specific activity in vitro by nick translation with DNA polymerase I. J. Mol. Biol. 113, 237-251.

Roise, D., Horvath, S. J., Tomich, J. M., Richards, J. H., and Schatz, G. (1986). A chemically synthesized pre-sequence of an imported mitochondrial protein can form an amphiphilic helix and perturb natura and artificial phospholipid bilayers. EMBO J. 5, 1327-1334.

Saiki, R. K., Gelfand, D. H., Stoffel, S., Scharf, S. J., Higuchi, R., Horn, G. T., Mullis, K. B., and Erlich, H. A. (1988). Primer-directed enzymatıc amplification of DNA with a thermostable DNA polymerase. Science 239, 487-491.

Sambrook, J., Fritsch, E. F., and Maniatis, T. (1989). Molecular ClonIng: A Laboratory Manual, Second Edition (Cold Spring Harbor, New York: Cold Spring Harbor Laboratory Press).

Sanders, S. L., and Schekman, R. (1992). Polypeptide translocation across the endoplasmic reticulum membrane. J. Biol. Chem. 267, 1379t-13794

Sanger, F., Nicklen, S., and Coulson, A. R. (1977). DNA sequencing with chain-terminating inhibitors. Proc. Natl. Acad. Sci. USA 74, 5463-

5467.

Schleyer, M., Schmidt, B., and Neupert, W. (1982). Requirement of a membrane potential for the posttranslational transfer of protein into mitochondria. Eur. J. Biochem. 125, 109-116

Schneider, H., Arretz, M., Wachter, E., and Neupert, W. (1990). Matrix processing peptidase of mitochondria: structure function relationships. J. Biol. Chem. 265, 9881-9887.

Schneider, H., Söllner, T., Dietmeier, K., Eckerskorn, C., Lottspeich, F., Trülzsch, B., Neupert, W., and Pfanner, N. (1991). Targeting of the master receptor MOM19 to mitochondria. Science 254, 1659-1662. Söliner, T., Griffiths, G., Pfaller, R., Pfanner, N., and Neupert, W. (1989). MOM19, an import receptor for mitochondrial precursor proteins. Cell $59,1061-1070$.
Söllner, T., Pfaller, R., Griffiths, G., Pfanner, N., and Neupert, W. (1990). A mitochondrial import receptor for the ADP/ATP carrier. Cell 62, 107-115.

Söllner, T., Rassow, J., and Pfanner, N. (1991). Analysis of mitochondrial protein import using translocation intermediates and specific antlbodies. Meth. Cell Biol. 34, 345-358.

Söllner, T., Rassow, J., Wiedmann, M., Schloßmann, J., Keil, P., Neupert, W., and Pfanner, N. (1992). Mapping of the protein import machinery in the mitochondrial outer membrane by crosslinking of translocation Intermediates. Nature 355, 84-87.

Steger, H. F., Söllner, T., Kiebler, M., Dietmeier, K. A., Pfaller, R., Trülzsch, K. S., Tropschug, M., Neupert, W., and Pfanner, N. (1990). Import of ADPIATP carrier into mitochondria: two receptors act in parallel. J. Cell Biol. 111, 2353-2363.

Tabor, S., and Richardson, C. C. (1987). DNA sequence analysis with a modified bacteriophage T7 DNA polymerase. Proc. Natl. Acad. Sci. USA $84,4767-4771$

Vestweber, D., Brunner, J., Baker, A., and Schatz, G. (1989). A 42K outer-membrane protein is a component of the yeast mitochondrial protein import site. Nature 341, 205-209.

von Heijne, G. (1986). Mitochondrial targeting sequences may form amphiphilic helices. EMBO J. 5, 1335-1342.

Wickner, W. T., and Lodish, H. F. (1985). Multiple mechanisms of protein insertion into and across membranes. Science 230, 400-407.

Wickner, W. T., Driessen, A. J. M., and Hartl, F.-U. (1991). The enzymology of protein translocation across the Escherichia coli plasma membrane. Annu. Rev. Biochem. 60, 101-124.

Young, R. A., and Davis, R. W. (1983). Yeast RNA polymerase Il genes: isolation with antibody probes. Science 222, 778-782.

Zimmermann, R., and Neupert, W. (1980). Transport of proteins into mitochondria: posttranslational transfer of ADP/ATP carrier into mitochondria in vitro. Eur. J. Bıochem. 109, 217-229.

\section{GenBank Accession Number}

The accession number for the sequence reported in this paper is X71021 